\title{
Signal Transduction Mechanism of Insulin and Insulin-Like Growth Factor-1
}

\author{
TAKASHI KADOWAKI, KAZUYUKI TOBE, RITSUKO HONDA-YAMAMOTO, \\ HiROYUKI TAMEMOTO, YASUSHI KABURAGI, KaORU MOMOMURA, KoJIRO UEKI, \\ YOSHIHIKO TAKAHASHI, TOSHIMASA YAMAUCHI, YASUO AKANUMA*, AND YosHIO YAZAKI
}

Third Department of Internal Medicine, Faculty of Medicine, University of Tokyo, Tokyo 113, and

* Institute for Diabetes Care and Research, Asahi Life Foundation, Tokyo 100, Japan

\begin{abstract}
Insulin and insulin-like growth factor-1 (IGF-1) are two structurally related hormones which produce similar biological activities such as metabolic and growth promoting actions. Their receptors, insulin and IGF-1 receptors, also share similarities in both structure and functions such as tyrosinespecific protein kinase. We identified insulin receptor substrate-1 (IRS-1) as a common substrate for insulin and IGF-1 receptor tyrosine kinases. We generated IRS-1 knockout mice and showed that IRS-1 plays a physiological role in signal transduction and biological actions of insulin and IGF-1. We also identified pp190 (IRS-2) as an alternative substrate for IRS-1.
\end{abstract}

Key words: Insulin, Insulin-like growth factor-1, Tyrosine kinase, Insulin receptor substrate-1

(Endocrine Journal 43 (Suppl): S33-S41, 1996)

\section{The Insulin Receptor and the IGF-1 Receptor}

The insulin receptor is composed of two distinct glycoproteins termed $\alpha$-subunit $(\mathrm{Mr}=135,000$ by sodium dodecyl sulfate-polyacrylamide gel electrophoresis [SDS-PAGE]) and $\beta$-subunit ( $\mathrm{Mr}=95,000$ by SDS-PAGE) to form a heterotetramer $\alpha 2 \beta 2[1,2]$. Both subunits are derived from a single proreceptor by proteolytic processing. Two alternatively spliced insulin receptor isoforms are described that differ by 12 animo acids near the $\mathrm{COOH}$ terminus of the $\beta$-subunit. The receptor gene, which is more than 150 kilobases in length and contains 22 exons, is located on the human chromosome $19 \mathrm{p}$ [3]. The insulin receptor is structurally related

Correspondence to: Dr. Takashi KADOWAKI, Third Department of Internal Medicine, Faculty of Medicine, University of Tokyo, 7-3-1 Hongo, Bunkyo-ku, Tokyo 113, Japan to the IGF-1 receptor and the insulin receptor-related receptor, an orphan receptor for which no ligand has been identified [4,5]. A comparison between the insulin receptor and the IGF-1 receptor amino acid sequence reveals $84 \%$ identity in their tyrosine kinase domains and $44 \%$ identity in their carboxyl terminal domain [4]. The IGF-1 receptor gene contains 21 exons. There is striking homology with the insulin receptor gene in overall size and in number and size of individual exons [6]. Two alternately spliced exon 14 of the IGF-1 receptors are described that differ in amino acid coding sequence Thr-Gly to Arg in the extracellular portion of the receptor $\beta$ subunit [7]. $\alpha \beta$ half receptor precursors of the insulin receptor and those of the IGF-1 receptor can assemble to generate hybrid holoreceptor species. Insulin/ IGF-1 hybrid receptors bind both ligand with high affinity and occupancy of either $\alpha$-subunit results in autophosphorylation reactions between $\beta$-subunits [5].

The $\alpha$-subunits of the insulin receptor and IGF-1 receptor are located outside of the cell and contain 
ligand-binding domains. Affinity labeling and mutational analyses have implicated the involvement of NH2-terminal domain and C-terminal domain of the insulin receptor $\alpha$-subunit in ligand binding [8-10], whereas the residues defining IGF-1 binding are present predominantly in the cysteine-rich domain of the IGF-1 receptor [8]. For example, substitution of lysine for asparagine at position 15 in the $\alpha$-subunit of the human insulin receptor, a mutation observed in a patient with a genetic form of insulin resistance impaired the affinity of insulin binding and the transport of receptors to the cell surface [9].

The $\beta$-subunit is a transmembrane protein possessing tyrosine-specific protein kinase activity in the intracellular domain [11] (Fig. 1). Insulin binding to the $\alpha$-subunit of the insulin receptor leads to the phosphorylation of the $\beta$-subunit of the receptor on tyrosine residues [11-13]. This in turn activates the intrinsic tyrosine-specific protein kinase activity [14]. Several studies suggest that this tyrosine protein kinase activity plays an important role in insulin signal transduction. Chou et al. [15] overexpressed in $\mathrm{CHO}$ cells mutated human insulin receptor by replacing lysine-*1018 (ATP-binding site) with several different amino acids. They found that none of these cells exhibited insulin-stimulated kinase activity, uptake of 2-deoxyglucose, S6 kinase activation, glycogen synthesis, thymidine uptake and internalization of insulin [15, our unpublished observation (Table 1)]. Therefore, the autophosphorylation and/or tyrosine kinase activity of the insulin receptor is necessary in mediating many, if not all, of the biological effects of insulin.

*according to the numbering system of Ullrich, et al. [1].
Similar results were observed with mutant IGF-1 receptor (lysine-substituted with alanine) [16]. We identified a mutation in the insulin receptor gene impairing the tyrosine kinase activity in a patient with insulin resistance [17]. In the mutant recep-

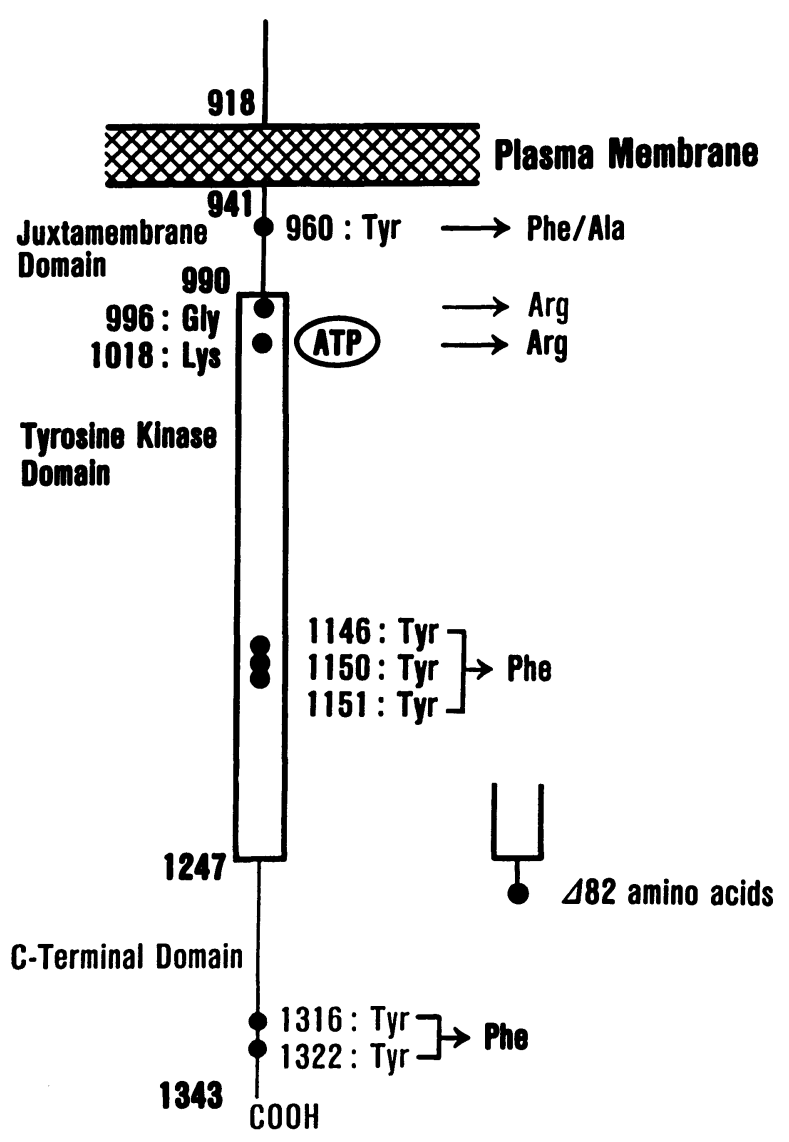

Fig. 1. Schematic representation of cytoplasmic domain of the human insulin receptor and mutant insulin receptors described in the manuscript.

Table 1. Summary of signalling and biological actions of mutant insulin receptors

\begin{tabular}{|c|c|c|c|c|c|c|}
\hline & $\begin{array}{c}\text { Tyrosine } \\
\text { kinase }\end{array}$ & $\begin{array}{c}\text { Auto- } \\
\text { phosphorylation }\end{array}$ & $\begin{array}{l}\text { pp185 } \\
\text { (IRS-1) }\end{array}$ & $\begin{array}{l}\text { 2DG } \\
\text { uptake }\end{array}$ & $\begin{array}{l}\text { Glycogen } \\
\text { synthesis }\end{array}$ & $\begin{array}{c}\text { DNA } \\
\text { synthesis }\end{array}$ \\
\hline \multicolumn{7}{|l|}{ Mutant insulin receptors } \\
\hline Gly $^{996} \rightarrow$ Arg & $(-)$ & $(-)$ & $(-)$ & $(-)$ & $(-)$ & $(-)$ \\
\hline Lys $^{1018} \rightarrow$ Arg & $(-)$ & $(-)$ & $(-)$ & $(-)$ & $(-)$ & $(-)$ \\
\hline Tyr $^{1146,1150,1151} \rightarrow$ Phe & $\downarrow \downarrow \downarrow$ & $\downarrow \downarrow \downarrow$ & $\downarrow \downarrow \downarrow$ & $\downarrow \downarrow \downarrow$ & $\downarrow \downarrow \downarrow$ & $\downarrow \downarrow \downarrow$ \\
\hline Try ${ }^{960 \rightarrow \text { Phe } / \text { Ala }}$ & $\mathrm{N}$ & $\mathrm{N}$ & $\downarrow \downarrow$ & $\downarrow \downarrow$ & $\downarrow \downarrow$ & $\downarrow \downarrow$ \\
\hline$\Delta \mathrm{C} 82$ & $\downarrow$ & $\downarrow$ & $\mathrm{N}$ & $\mathrm{N}$ & $\mathrm{N}$ & $\mathrm{N}$ \\
\hline $\mathrm{Tyr}^{1316,1322 \rightarrow \text { Phe }}$ & $\mathrm{N}$ & $\mathrm{N}$ & $\mathrm{N}$ & $\mathrm{N}$ & $\mathrm{N}$ & $\uparrow$ \\
\hline
\end{tabular}

$(-)$, abolished; $\downarrow$, slightly decreased; $\downarrow \downarrow$, moderately decreased; $\downarrow \downarrow \downarrow$, severely decreased; N, normal. (references 18, 20, 21, 23, 25, Momomura K and Kadowaki T, unpublished observations). 
tor, valine-996 is substituted for glycine, the third glycine in the highly conserved Gly-X-Gly-X-X-Gly sequence in the receptor's ATP-binding site. By transfecting the mutant receptor cDNA into $\mathrm{CHO}$ cells, we found that the receptor's tyrosine kinase activity was impaired by the Val-996 mutation. Val-996 mutation also inhibited insulin-stimulated uptake of 2-deoxyglucose and glycogen synthesis [18] (Table 1). This observation suggested that a defect in the insulin receptor tyrosine kinase could interfere with insulin action in vivo, and that mutations in the insulin receptor gene can cause insulin resistance and diabetes.

The tyrosine kinase domain of the insulin receptor and the IGF-1 receptor contains the ATP binding domain and 3 tyrosine residues in the Tyr-X-X-X-Tyr-Tyr motif (Fig. 1). Three tyrosine autophosphorylation sites in the kinase domain (Tyr-1146, Tyr-1150, and Tyr-1151 of the insulin receptor and Tyr-1146, Tyr-1150, and Tyr-1151 in the IGF-1 receptor) seem to be essential for receptor kinase activity and biological effects $[19$, our unpublished observation) (Table 1)].

Several functional domains other than tyrosine kinase domain have been defined in the $\beta$-subunit of the insulin receptor and the IGF-1 receptor (Fig. 1). The intracellular juxtamembrane region of the insulin receptor $\beta$-subunit plays an important role in signal transduction. Tyr-960 of the insulin receptor resides in an NPXY motif which also exists in other tyrosine kinase receptors and oncogene products including the IGF-1 receptors (Tyr-950) (Fig. 1). Replacement of Tyr-960 with phenylalanine or alanine impairs phosphorylation of insulin receptor substrate-1 (IRS-1) and Shc without disturbing autophosphorylation of the $\beta$-subunit and the tyrosine kinase activity, raising the possibility that Tyr-960 and NPXY motif play pivotal roles in the recognition of these substrates [20-22] (Table 1). In addition to signal transduction, the juxtamembrane region of the insulin receptor and IGF-1 receptor is required for coated pit-mediated internalization of insulin and IGF-1, respectively [20-22].

Protein tyrosine kinases often contain a $\mathrm{COOH}-$ terminal tail that extends beyond the end of the tyrosine kinase homology region. The $\mathrm{COOH}$ tail of the insulin receptor contains two autophosphorylation sites at tyrosine-1316 and tyrosine-1322 (Fig. 1). The $\mathrm{COOH}$ tail of IGF-1 receptor contains
3 possible autophosphorylation sites at tyrosine1250, tyrosine-1251, and tyrosine-1316. Autophosphorylation sites in the $\mathrm{COOH}$ tail of the insulin receptor may behave inhibitory to mitogenic signaling, while those of the IGF-1 receptor may behave stimulatory to tumorigenic signaling. Cells overexpressing mutant insulin receptor replacing tyrosine-1316 and tyrosine-1322 with phenylalanine exhibited enhanced activation of mitogen-activated protein (MAP) kinase and S6 kinase, and increased sensitivity of thymidine uptake in response to insulin, while insulin-stimulated autophosphorylation and kinase activity were normal [23] (Table 1). Cells overexpressing mutant IGF-1 receptor replacing tyrosine-1250, 1251 or tyrosine-1316 with phenylalanine exhibiting reduced tumorigenic potentials without significantly inhibiting receptor autophosphorylation and kinase activity [24]. Cells overexpressing mutant insulin receptor lacking 82 amino acids $(\Delta \mathrm{C} 82)$ from the $\mathrm{COOH}$ terminus exhibited impaired autophosphorylation of the insulin receptor while tyrosine phosphorylation of IRS-1 were comparable to cells overexpressing [25]. Thus, $\mathrm{COOH}$ tail of the insulin receptor seems to be involved in the interaction of insulin receptor with IRS-1.

\section{Substrates for Insulin Receptor and IGF-1 Receptor Kinase}

Using anti-phosphotyrosine antibodies, White et al. [26] reported a phosphotyrosine-containing protein of relative Mr 185,000 (pp185) on SDS-PAGE, which appeared during the initial responses of hepatoma cells to insulin binding. Tyrosine phosphorylation of pp185, later named IRS-1, reaches maximum within $30 \mathrm{sec}$ after exposure of the cells to insulin and exhibits a dose-response curve similar to that of receptor autophosphorylation [27-30]. pp185 (IRS-1) is tyrosine phosphorylated in physiological target tissues of insulin such as liver, muscle, and adipocytes $[29,30]$. We showed that pp185 (IRS-1) is also tyrosine phosphorylated with IGF-1 [28, 31, 32]. We demonstrated that tyrosine phosphorylation of pp185 (IRS-1) in response to insulin occurred via the insulin receptor and that of pp185 (IRS-1) in response to IGF-1 occurred via the IGF-1 receptor using specific antisera to these receptors [28]. Thus, pp185 (IRS-1) is a common 
substrate for the insulin and IGF-1 receptor tyrosine kinases [28]. In contrast, pp185/IRS-1 does not serve as a substrate for EGF receptor [28] or PDGF receptor. Recently, tyrosine phosphorylation of IRS-1 is reported in response to several interleukins, interferons, angiotensin II, and growth hormone (Yamauchi T, Tsushima T, Kadowaki T, unpublished observation).

IRS- 1 contains 21 potential tyrosine phosphorylation sites and over 30 potential serine/threonine phosphorylation sites. In its animo terminus, IRS1 contains a pleckstrin-homology $(\mathrm{PH})$ domain and a phosphotyrosine-binding (PTB) domain. $\mathrm{PH}$ domain and PTB domain of IRS-1 are thought to be important for receptors coupling between insulin and IGF-1 receptors and IRS-1.

The role of IRS-1 in signal transduction of insulin has been suggested by several lines of evidence. In $\mathrm{CHO}$ cells overexpressing mutant insulin receptors (Tyr-960 $\rightarrow$ Phe/Ala, $\Delta$ C82), insulin actions appears to be parallel with the extent of tyrosine phosphorylation of IRS-1 rather than that of the receptor itself $[20-22,25]$. For example, replacement of Tyr-960 with phenylalanine caused an impairment of IRS- 1 tyrosine phosphorylation and a concomitant decrease in insulin's biological actions despite normal insulin receptor autophosphorylation [20-22].

\section{Molecules that Bound to IRS-1}

Tyrosine phosphorylation of IRS-1 provides binding sites for several distinct Src homology 2 (SH2) proteins and may mediate multiple signaling pathways. Indeed, IRS-1 binds the $85-\mathrm{kDa}$ subunit of phosphatidylinositol 3-kinase (PI 3-kinase p85) through interaction with Tyr-X-X-Met motifs, thereby activating PI 3-kinase [33]. This pathway may be implicated in the translocation of glucose transporters and also activation of glycogen synthase [34]. IRS-1 also binds Ash/Grb2 (abundant src homology/growth factor receptor bound protein 2), a $23 \mathrm{kDa}$ protein with one $\mathrm{SH} 2$ domain and two SH3 domains [35]. Ash/Grb2 associates with IRS-1 or Shc by its $\mathrm{SH} 2$ domain and associates with Sos with its $\mathrm{SH} 3$ domain. These signaling pathways may activate p21ras and the MAP kinase cascade [36-38]. We have recently shown Csk tyrosine kinase which is a negative regulator src-family tyrosine kinases can form a complex with IRS-1 in response to insulin, which appears to be implicated in insulin-induced tyrosine dephosphorylation of proteins at the focal adhesion such as focal adhesion kinase (FAK) [39]. Moreover, IRS-1 has binding sites for Syp and Nck and other SH2 signaling molecules.

\section{Growth Retardation and Insulin Resistance in IRS-1 Deficient Mice}

To understand the roles of IRS- 1 in normal physiology, we and others made mice with a targeted disruption of the IRS-1 gene locus [40, 41]. Growth of the homozygous IRS-1 knockout mice was retarded. At the age of 3,8 , and 15 weeks, the weight was about $30 \%$ less than that of normal littermates (Fig. 2A); the serum IGF-1, IGF-2 and growth hormone levels were normal in the mutant mice (Hizuka N, personal communication). The growth retardation of the embryos was apparent at 15.5 embryonic day and the weight of homozygous IRS1 knockout embryos was about $80 \%$ of that of normal and heterozygous embryos at 18.5 embryonic day.

The drop in the blood glucose levels after injection of human insulin was significantly smaller in homozygous mutant mice than those of heterozygous mutant and wild-type mice (Fig. 2B). Similar results were observed with IGF-1 injection (Fig. 2C) and also with IGF-2 (data not shown). Thus, homozygous mutant mice have resistance to IGF-1 and IGF-2 in addition to insulin. Stimulation of glucose transport activity in the isolated adipocytes with insulin [40] and that in soleus muscle with insulin and IGF-1 [42] were significantly impaired in homozygous mutant mice compared with that of the wild-type mice. In contrast, insulin-stimulated biological activities in the liver such as glycogen synthesis were normal (see below). There was no significant difference in blood glucose levels among the three genotypes during an oral glucose load (Fig. 2D). However, the serum insulin levels before and after glucose load were significantly higher in the homozygous mutant mice (Fig. 2D). Thus, IRS-1 knockout mice show mild to moderate post-receptor insulin resistance in the muscle yet normal glucose tolerance by compensatory hyperinsulinemia from pancreatic $\beta$-cells, 
which resembles the phenotype of NIDDM at the prediabetic stage [40,42].

This study has shown that IRS-1 is required at least in part for the pre- and postnatal growthpromoting effect and glucose-lowering effect of insulin, IGF-1, and IGF-2. The growth retardation of the IRS-1 knockout mice was milder than those of insulin receptor knockout mice [43] and leprechaunism, human insulin receptor deficient state [44], and also milder than that of IGF-1 receptor knockout mice [45], suggesting the existence of both IRS-1 dependent and IRS-1 independent pathways in signal transduction through insulin and IGF-1 receptor tyrosine kinases (Fig. 3). We studied insulin-stimulated signalling pathways and biological actions in IRS-1 deficient mice [42] (Table 2). Insulin-stimulated PI3 kinase activity in anti-phosphotyrosine antibody immunoprecipitates was reduced in the muscle from IRS-1 deficient mice, whereas it was normal in the liver. Moreover, insulin-stimulated MAP kinase activity was also reduced in the muscle, whereas it was again normal in the liver. Consistent with PI3 kinase and MAP kinase activities, insulin-stimulated glucose transport, glycogen synthesis and protein synthesis was reduced in the muscle, whereas insulin-stimulated glycogen synthesis was normal in the liver. Thus, contribution of IRS-1 independent pathway seemed to be more significant in the liver than in the muscle [42].
A.

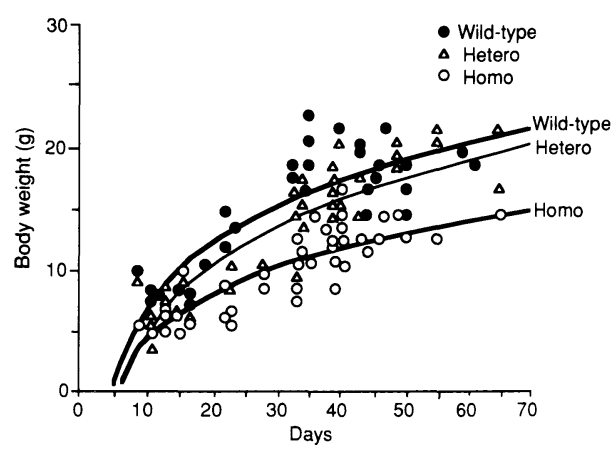

C. IGF-1 tolerance test

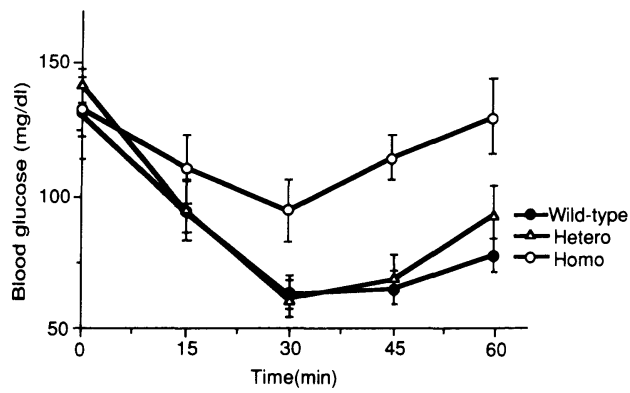

B. Insulin tolerance test

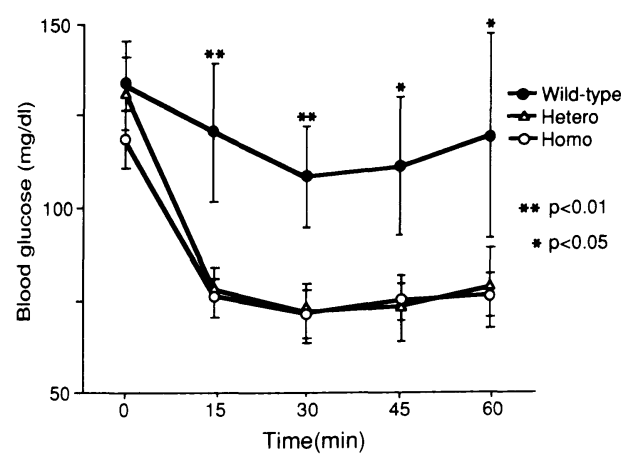

D. Glucose tolerance test
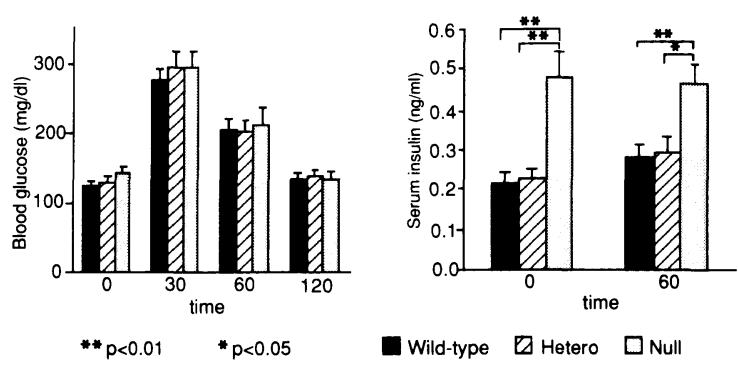

Fig. 2. (A) Growth curve. (B) Insulin tolerance test. (C) IGF-1 tolerance test. Homozygous (unfilled circles), heterozygous (triangles) and wild-type (filled circles) mice were injected either with human insulin or IGF-1 into the peritoneal cavity and the blood glucose levels were determined at the indicated times. ${ }^{*}$ indicates $P<0.01$ and * indicates $P<0.05$. (D) Blood glucose and serum insulin during an oral glucose load. The wild-type (filled bars), heterozygous (hatched bars), and the homozygous mutant mice (unfilled bars) were given glucose, and the blood glucose (left panel) and serum insulin (right panel) levels determined at the indicated time points. The bars show the SEM. The serum insulin levels of the homozygous mice before and after glucose load $(0.41 \pm 0.04$ $\mathrm{ng} \mathrm{m} \mathrm{m}^{-1}$ to $\left.0.46 \pm 0.04 \mathrm{ng} \mathrm{m}^{-1}\right)$ were significantly higher than those of the wild type $\left(0.24 \pm 0.02 \mathrm{ng} \mathrm{ml}^{-}\right.$ 1 to $\left.0.311 \pm 0.03 \mathrm{ng} \mathrm{ml}^{-1}\right)$ and heterozygous mice $\left(0.24 \pm 0.02 \mathrm{ng} \mathrm{ml}^{-1}\right.$ to $\left.0.37 \pm 0.04 \mathrm{ng} \mathrm{ml}^{-1}\right)(P<0.01$ and $P<0.05$, respectively)[40]. 


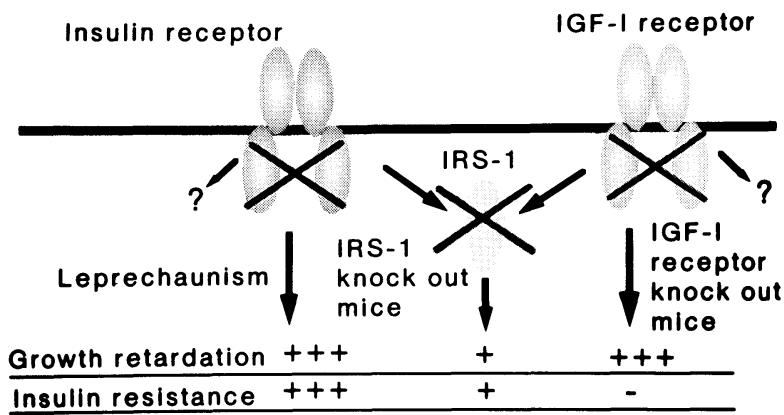

Fig. 3. Comparisons of phenotypes of insulin receptor deficiency, IGF-1 receptor deficiency, and IRS-1 deficiency.
Table 2. Insulin-stimulated signalling pathways and biological actions in IRS-1 deficient mice

\begin{tabular}{lcc}
\hline & Muscle & Liver \\
\hline P13 kinase & $\downarrow \downarrow$ & normal \\
MAP kinase & $\downarrow \downarrow$ & normal \\
IRS-1 & $(-)$ & $(-)$ \\
Shc & $\rightarrow$ or $\uparrow$ & $\rightarrow$ or $\uparrow$ \\
IRS-2 & $=20 \%$ & $100 \%$ \\
Glucose transport & $\downarrow \downarrow$ & N.A. \\
Glycogen synthesis & $\downarrow \downarrow$ & normal \\
Protein synthesis & $\downarrow \downarrow$ & N.D. \\
\hline
\end{tabular}

$\rightarrow$, unaltered; $\uparrow$, increased; $\downarrow \downarrow$, markedly decreased; (-), absent; N.A., not applicable; N.D., not determined.

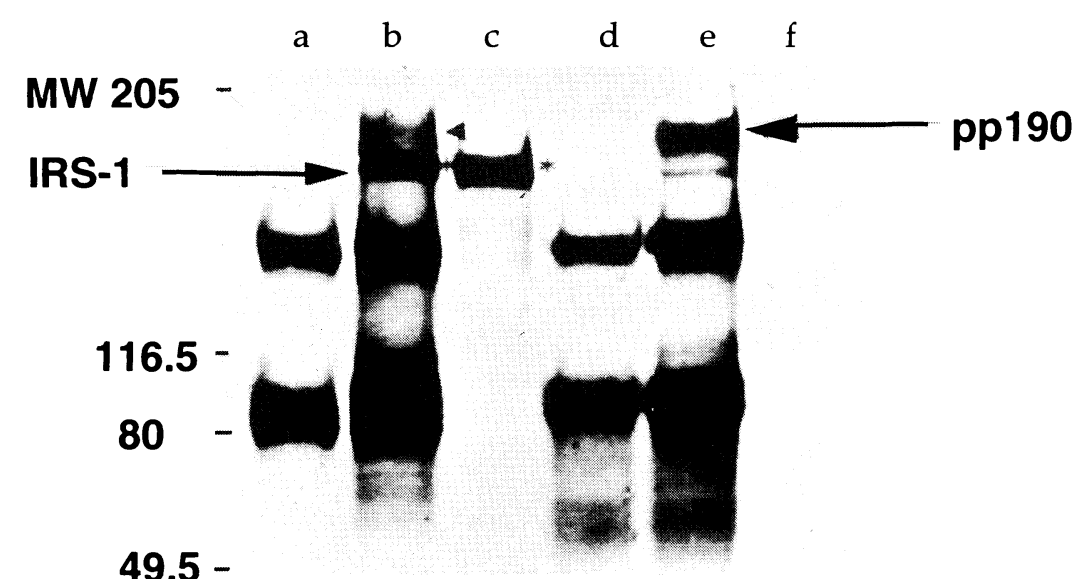

\begin{tabular}{|c|c|c|c|c|}
\hline insulin & - & + & + & + \\
\hline genotype & \multicolumn{2}{|c|}{$+/ t$} & \multicolumn{2}{|c|}{$-/-$} \\
\hline $\begin{array}{l}\text { immuno- } \\
\text { precipitation }\end{array}$ & $\alpha-P Y$ & $\begin{array}{l}\alpha- \\
\text { IRS-1 }\end{array}$ & $\alpha-P Y$ & $\begin{array}{l}\alpha- \\
\text { IRS-1 }\end{array}$ \\
\hline blotting & \multicolumn{4}{|c|}{$\alpha-P Y$} \\
\hline
\end{tabular}

Fig. 4. Detection of pp190 in insulin-injected wild-type or IRS-1 deficient mice. Wildtype (lanes $a, b, c)$ or IRS-1 deficient mice (lanes $d, e, f$ ) were injected with saline (lanes a, d) or insulin (lanes b, c, e, f) via portal veins. At $75 \mathrm{sec}$, livers were removed, homogenized in buffer $\mathrm{A}$ and centrifuged. The supernatants were subjected to immunoprecipitation with $\alpha$-PY (lanes $a, b, d, e$ ) or $\alpha$-IRS-1 (1-6) (lanes c,f) followed by western blotting with RC20. A minor tyrosinephosphorylated band around $\mathrm{Mr} 160-\mathrm{kDa}$ as shown in lane e was detected in some, but not all, of the experiments. However, since this band was not immunoprecipitated with $\alpha$-IRS-1 (1-6) as shown in lane f, it is not IRS-1 [46].

\section{Identification of pp190/IRS-2 in IRS-1 Deficient Mice}

In order to identify IRS-1-independent pathways, we studied insulin-stimulated tyrosine phospho- rylated proteins in the liver of wild-type or homozygous mutant mice by injecting insulin via portal veins [46]. We observed a $160-\mathrm{kDa}$ tyrosine phosphorylated protein (IRS-1) in liver of insulininjected wild-type mice (Fig. 4). In addition to IRS-1, we also observed another weakly tyrosine 
phosphorylated protein of an Mr 190-kDa (pp190) which was not recognized by anti IRS-1 antibody (Fig. 4). In homozygous IRS-1 deficient mice, we observed pp190 in response to insulin. Tyrosine phosphorylation of pp190 was significantly increased in insulin-injected IRS-1 deficient mice compared with that in insulin-injected wild-type mice (Fig. 4). Tyrosine phosphorylation of Shc was not significantly increased. We also showed that tyrosine phosphorylated pp190/IRS-2 is able to bind both p85 of PI 3-kinase and Ash/Grb2 [46]. These data suggested that insulin-stimulated tyrosine phosphorylation of pp190, which was immunologically distinct from IRS-1 yet functionally similar to IRS-1, was increased in IRS-1 deficient mice compared with that in wild-type mice, thus compensating the effects of IRS-1 deficiency.

In fact, pp190, cloned by Sun et al. and named IRS-2 [47], has many structural homologies with IRS-1 including P85 PI3-kinase and Ash/Grb2 binding sites. We found that the amount of tyrosine-phosphorylated IRS-2 (in IRS-1 deficient mice) was roughly equal to that of IRS-1 (in wildtype mice) in the liver, whereas it was only 20 to $30 \%$ of that of IRS-1 in muscles, suggesting biological roles of IRS-2 as well as IRS-1 in insulin actions. Generation of IRS-2 knockout mice as well as IRS$1 /$ IRS-2 double knockout mice should define the roles of IRS-1/IRS-2 system in biological actions of insulin and IGF-1.

\section{Acknowledgment}

This work was supported by grants from the Juvenile Diabetes Foundation International to $\mathrm{T}$. $\mathrm{K}$., by a grant for diabetes rèsearch from Ohtsuka Pharmaceutical Co., Ltd., to T.K., and by a grant from Taisho Pharmaceutical Co., Ltd., to T.K. Dr. Ritsuko Honda-Yamamoto played a major role in writing this review.

\section{References}

1. Ullrich A, Bell JR, Chen EY, Herrera R, Petruzzelli LM, Dull TJ, Gray A, Coussens L, Liao Y-C, Tsubokawa M, Mason A, Seeburg PH, Grunfeld C, Rosen OM, Ramachandran J (1985) Human insulin receptor and its relationship to the tyrosine kinase family of oncogenes. Nature 313: 756-761.

2. Ebina $\mathrm{Y}$, Ellis L, Jarnagin K, Edery M, Graf L, Clauser E, Qu J, Masiarz F, Kan YW, Goldfine ID, Roth RA, Rutter WJ (1985) The human insulin receptor cDNA: The structural basis for hormoneactivated transmembrane signaling. Cell 40: 747-758.

3. Seino S, Seino M, Nishi S, Bell GI (1989) Human insulin receptor gene and characterization of its promoter. Proc Natl Acad Sci USA 86: 114-118.

4. Ullrich A, Gray A, Tam AW, Yang Feng T, Tsubokawa M, Collins C, Henzel W, Bon TL, Kathuria S, Chen E, Jacobs S, Francke U, Ramachandran J, Fujita-Yamaguchi Y (1986) Insulin-like growth factor 1 receptor primary structure: Comparison with insulin receptor suggests derminants that define functional specificity. $E M B O$ J 5: 2503-2512.

5. Werner H, LeRoith D (1995) Insulin-like growth factor 1 receptor: Structure, signal transduction, and function. Diabetes Reviews 3: 28-37.

6. Abott AM, Bueno R, Pedrini MT, Murray JM, Smith RJ (1992) Insulin-like growth factor 1 receptor gene structure. J Biol Chem 267: 10759-10763.

7. Condorelli G, Bueno R, Smith R, Smith R (1994) Two alternatively spliced forms of the human insulin-like growth factor 1 receptor have distinct biological activities and internalization kinetics. $J$ Biol Chem 269: 850-8516.

8. Schumacher R, Branderburg D, Mostaf L, Ullrich A, Schlessinger J (1991) Insulin and insulin-like growth factor 1 binding specificity is determined by distinct regions of their cognate receptors. J Biol Chem 266: 19288-19295.

9. Kadowaki T, Kadowaki H, Accili D, Taylor SI (1990) Substitution of lysine for asparagine at position 15 in the $\alpha$-subunit of human insulin receptor. A mutation that impairs transport of receptors to the cell surface and decreases the affinity of insulin binding. J Biol Chem 265: 19143-19150.

10. Kadowaki H, Kadowaki T, Marcus-Samuels B, Cama A, Taylor SI (1990) Mutagenesis of lysine460 in the human insulin receptor. Effects on receptor recycling and cooperative interactions among binding sites. J Biol Chem 265: 21285-21296.

11. Kasuga M, Karlsson FA, Kahn CR (1982) Insulin stimulates the phosphorylation of the 95,000-dalton subunit of its own receptor. Science 215: 185-187.

12. Kasuga M, Zick $Y$, Blithe DL, Karlsson FA, Haring HU, Kahn CR (1982) Insulin stimulation of phosphorylation of the $\beta$-subunit of the insulin receptor: 
Formation of both phosphoserine and phosphotyrosine. J Biol Chem 257: 9891-9894.

13. Roth RA, Cassell MP (1983) Insulin receptor: Evidence that it is a protein kinase. Science 219: 299-301.

14. Rosen OM, Herrera R, Olowe Y, Petruzzelli LM, Cobb MH (1983) Phosphorylation activates the insulin receptor tyrosine protein kinase. Proc Natl Acad Sci USA 80: 3237-3240.

15. Chou CK, Dull TJ, Russell DS, Gherzi R, Lebwohl D, Ullrich A, Rosen OM (1987) Human insulin receptors mutated at the ATP-binding site lack protein tyrosine kinase activity and fail to mediate postreceptor effects of insulin. J Biol Chem 262: 1842-1847.

16. Kato H, Faria TN, Stannard BS, Roberts CTJr, LeRoith D (1993) Role of tyrosine kinase activity in signal transduction by the insulin-like growth factor-1 (IGF-1) receptor. J Biol Chem 268: 2655-2661.

17. Odawara M, Kadowaki T, Yamamoto R, Shibasaki Y, Tobe K, Accili D, Bevins S, Mikami Y, Matsuura N, Akanuma Y, Takaku F, Taylor SI, Kasuga M (1989) Human diabetes associated with a mutation in the tyrosine kinase domain of the insulin receptor. Science 245: 66-68.

18. Yamamoto-Honda R, Koshio O, Tobe K, Shibasaki Y, Momomura K, Odawara M, Kadowaki T, Takaku F, Akanuma Y, Kasuga M (1990) Phosphorylation state and biological function of a mutant human insulin receptor Val 1996. J Biol Chem 265: 1477714783.

19. Wilden PA, Kahn CR, Siddle K, White MF (1992) Insulin receptor kinase domain autophosphorylation regulates receptor enzymatic function. $J$ Biol Chem 267: 16660-16668.

20. Kaburagi Y, Momomura K, Yamamoto-Honda R, Tobe K, Tamori Y, Sakura H, Akanuma Y, Yazaki Y, Kadowaki T (1993) Site-directed mutagenesis of the juxtamembrane domain of the human insulin receptor. J Biol Chem 268: 16610-16622.

21. Kaburagi Y, Yamamoto-Honda R, Tobe K, Ueki K, Yachi M, Akanuma Y, Stephens RM, Kaplan D, Yazaki Y, Kadowaki T (1995) The role of the NPXY motif in the insulin receptor in tyrosine phosphorylation of insulin receptor substrate-1 and Shc. Endocrinology 34337-34443.

22. White MF, Livingston JN, Backer JM, Lauris V, Dull TJ, Ulrich A, Kahn CR (1988) Mutation of the insulin receptor at tyrosine 960 inhibits signal transmission but does not affect its tyrosine kinase activity. Cell 54: 641-649.

23. Ando A, Momomura K, Tobe K, Yamamoto-Honda R, Sakura H, Tomori Y, Kaburagi Y, Koshio O, Akanuma Y, Yazaki Y, Kasuga M, Kadowaki T (1992) Enhanced insulin-induced mitogenesis and mitogen-activated protein kinase activities in mutant insulin receptors with substitution of two
$\mathrm{COOH}$-terminal tyrosine autophosphorylation sites by phenylalanine. J Biol Chem 267: 12788-12796.

24. Blakesley VA, Kalebic T, Helman LJ, Stannard B, Faria TN, Roberts CT Jr, LeRoith D (1996) Tumorigenic and mitogenic capacities are reduced in transfected fibroblasts expressing mutant insulinlike growth factor-1 (IGF-1) receptors. The role of tyrosine residues 1250, 1251, and 1316 in the carboxy-terminus of the IGF-1 receptor. Endocrinology 137: 410-417.

25. Honda-Yamamoto R, Kadowaki T, Momomura K, Tobe K, Tamori Y, Shibasaki Y, Mori Y, Kaburagi Y, Koshio O, Akanuma Y, Yazaki Y, Kasuga M (1993) Normal insulin receptor substrate-1 phosphorylation in autophosphorylation-defective truncated insulin receptor. J Biol Chem 268: 1685916865.

26. White MF, Maron $\mathrm{R}, \mathrm{Kahn} \mathrm{CR}$ (1985) Insulin rapidly stimulates tyrosine phosphorylation of a $\mathrm{Mr}$ 185,000 protein in intact cells. Nature 318: 183-186.

27. Kasuga M, Izumi T, Tobe K, Shiba K, Momomura K, Tashiro-Hashimoto Y, Kadowaki T (1990) Substrates for insulin receptor kinase. Diabetes Care 13: 317-325.

28. Kadowaki T, Koyasu S, Nishida E, Tobe K, Izumi T, Takaku F, Sakai H, Yahara I, Kasuga M (1987) Tyrosine phosphorylation of common and specific sets of cellular proteins rapidly induced by insulin, insulin-like growth factor-I and epidermal growth factor in KB cells. J Biol Chem 262: 7342-7350.

29. Tobe K, Koshio T, Tashiro-Hashimoto Y, Takaku F, Akanuma Y, Kasuga M (1990) Immunological detection of phosphotyrosine-containing proteins in rat livers after insulin injection. Diabetes 39: 528533.

30. Momomura K, Tobe K, Seyama Y, Takaku F, Kasuga $M$ (1988) Insulin-induced tyrosine phosphorylation in intact rat adipocytes. Biochem Biophys Res Commun 155: 1181-1186.

31. Izumi T, White MF, Kadowaki T, Takaku F, Akanuma Y, Kasuga M (1987) Insulin-like growth factor I rapidly stimulates tyrosine phosphorylation of a Mr 185,000 protein in intact cells. J Biol Chem 262: 1282-1287.

32. Takahashi Y, Tobe K, Akanuma Y, Yazaki Y, Kadowaki T (1996) Signal transduction pathways of insulin-like growth factor-1 and epidermal growth factor in skin fibroblasts from an insulinresistant patient with a mutation in the insulin receptor gene. Endocrinology (In press).

33. Yamamoto-Honda R, Honda Z, Ueki K, Tobe K, Kaburagi Y, Takahashi Y, Tamemoto H, Akanuma Y, Suzuki T, Itoh K, Yazaki Y, Kadowaki T (1996) Mutant insulin receptor substrate-1 unable to activate P13 kinase failed to mediate insulin-stimulated maturation of xenopus laevis oocytes. J Biol Chem (In press) 
34. Yamamoto-Honda R, Tobe K, Kaburagi Y, Ueki K, Asai S, Yachi M, Shirouzu M, Yodoi J, Akanuma Y, Yokoyama S, Yazaki Y, Kadowaki T (1995) Upstream mechanisms of glycogen synthase activation by insulin and insulin-like growth factor-I. J Biol Chem 270: 2729-2374.

35. Tobe K, Matuoka K, Tamemoto H, Ueki K, Noguchi T, Matsuda M, Hattori S, Fukui Y, Akanuma Y, Yazaki Y, Takenawa T, Kadowaki T (1993) Insulin stimulates association of insulin receptor substrate1 (IRS-1) with the protein abundant Src homology (Ash). J Biol Chem 268: 11167-11171.

36. Tobe K, Kadowaki T, Hara K, Tamemoto H, Ueki K, Akanuma Y, Nishida E, Yazaki Y (1992) Sequential activation of MAP kinase activator, MAP kinase and S6 kinase II in rat liver injected with insulin. J Biol Chem 267: 21089-21097.

37. Tobe K, Kadowaki T, Tamemoto H, Ueki K, Hara K, Koshio O, Momomura K, Gotoh Y, Nishida E, Akanuma Y, Yazaki Y, Kasuga M (1991) Insulin and 12-O-tetradecanoylphorbol 13-acetate (TPA) activation of two immunologically distinct MBP/ MAP2 kinases via de novo phosphorylation of threonine and tyrosine residues. J Biol Chem 266: 24793-24803.

38. Ueki K, Matsuda S, Tobe K, Gotoh $Y$, Tamemoto $H$, Yachi M, Akanuma Y, Yazaki Y, Nishida E, Kadowaki T (1994) Feedback regulation of mitogen-activated protein kinase kinase kinase activity of c-Raf-1 by insulin and phorbol ester stimulation. J Biol Chem 269: 15756-15761.

39. Tobe K, Sabe H, Yamamoto T, Yamauchi T, Asai S, Kaburagi Y, Tamemoto H, Ueki K, Kimura $H$, Akanuma Y, Yazaki Y, Hanafusa H, Kadowaki T (1996) Csk enhances insulin-stimulated dephosphorylation of focal adhesion proteins. Mol Cell Biol 16: $4765-4772$.
40. Tamemoto $H$, Kadowaki T, Tobe K, Yagi T, Sakura H, Hayakawa T, Terauchi Y, Ueki K, Kaburagi Y, Satoh S, Sekihara H, Yoshioka S, Horikoshi H, Furuta Y, Ikawa Y, Kasuga M, Yazaki Y, Aizawa S (1994) Insulin resistance and growth retardation in mice lacking insulin receptor substrate-1. Nature 372: 182-186.

41. Araki E, Lipes MA, Patti ME, Brüning JC, Johnson RS, Kahn CR (1994) Alternative pathway of insulin signaling in mice with targeted disruption of the IRS-1 gene. Nature 372: 186-190.

42. Yamauchi T, Tobe $\mathrm{K}$, Tamemoto $\mathrm{H}$, Ueki $\mathrm{K}$, Kaburagi Y, Yamamoto-Honda R, Takahashi Y, Yoshizawa F, Aizawa S, Akanuma Y, Sonenberg N, Yazaki Y, Kadowaki T (1996) Insulin signalling and insulin actions in the muscle and liver of insulin resistant IRS-1 deficient mice. Mol Cell Biol 16:30743084.

43. Accili D, Drago J, Lee EJ, Johnson MD, Cool MH, Salvatore P, Asico LD, José PA, Taylor SI, Westphal H (1996) Nature Genetics 12: 106-109.

44. Taylor SI (1992) Molecular mechanisms of insulin resistance. Lessons from patients with mutations in the insulin receptor gene. Diabetes 41: 1473-1490.

45. Liu JP, Baker J, Perkins A, Robertson EJ, Efstratiadis A (1993) Mice carrying null mutations of the genes encoding insulin-like growth factor I (lgf-1) and type 1 IGF receptor (lgflr). Cell 75: 59-72.

46. Tobe K, Tamemoto $H$, Yamauchi T, Yazaki $Y$, Kadowaki T (1995) Identification of a 190-kDa protein as a novel substrate for the insulin receptor kinase functionally similar to insulin receptor substrate-1. J Biol Chem 270: 5698-5701.

47. Sun XJ, Wang LM, Zhang Y, Yenush L, Myers, MG Jr, Glasheen E, Lane WS, Pierce JH, White MF (1995) Role of IRS-2 in insulin and cytokine signalling. Nature 377: 173-177. 